\title{
PHYSIOLOGICAL ASPECTS OF IN VITRO-GROWN \\ COCONUT (Cocos nucifera L.) \\ PLANTS DURING ACCLIMATIZATION
}

\author{
By \\ C S Ranasinghe, L K Weerakoon, Y M H Liyanage and \\ D T Mathes ${ }^{l}$
}

\begin{abstract}
The physiological status of in vitro-grown coconut (Cocos nucifera L.) plants during acclimatization was studied using nursery-raised seedlings as the control. The percentage of open stomata in leaves of in vitro-grown coconut plants was high at the initial stage of acclimatization but decreased during the course of acclimatization indicating an improvement in stomatal regulation. A progressive increase in the stomatal density, epicuticular wax deposition and leaf thickness in in vitro-grown plants was observed during acclimatization. As a result of the low light intensity, the epidermal cells of in vitro-grown plants were narrower and longer when compared to the control. With the exposure of plants to increased light intensity, the cells became wider and shorter as observed in the control.

The leaf chlorophyll content was high in in vitro-grown plants under low light intensity. With increasing light intensity, a reduction in leaf chlorophyll content in vitro-grown plants was observed and at the later stages of acclimatization, it was comparable to that of the control. Variations in the rates of photosynthesis and transpiration in vitro-grown plants were observed in response to the changing environmental conditions. However, at the end of acclimatization, where the plants were ready to be transferred to the field, the physiological statuses of in vitro-grown coconut plants were comparable to that of nursery raised seedlings. The present study revealed that the embryo-cultured coconut plants could adjust well to the changing environmental conditions during acclimatization.
\end{abstract}

\section{INTRODUCTION}

Embryo culture technology is a valuable tool which facilitates efficient collection, exchange and conservation of coconut germplasm. Further, it is the only channel open for rescuing embryos of non-germinating and economically important types of coconut such as Makapuno and Dikiri. Hence, techniques used for in vitro culture of embryos and ex vitro hardening of resulting plants need to be optimized in order to achieve maximum possible success from recovery of embryos to field establishment.

During the transfer of in vitro-grown plants to ex vitro, physiological status of in in vitrogrown plants is an important factor, which determines the success rate during acclimatization (Derbergh, 1991). The different growth conditions during in vitro growth, low light intensity, artificial gas atmosphere, high relative humidity and high sucrose level in the culture medium, could lead to alterations in leaf anatomy (Rillo et al., 1988) and physiological status of the plant (Zacchini et al., 1997). The in vitro-grown plants, taken from an aseptic environment where temperature, light and humidity were controlled are extremely fragile. Therefore, it is important to study various anatomical, physiological and biochemical parameters of in vitro-raised plants during acclimatization as they would provide valuable clues in refining the current acclimatization procedure. To date, very little work has been done on physiological status of in vitro-grown coconut plants during

\footnotetext{
${ }^{1}$ Coconut Research Institute, Lunuwila, Sri Lanka
} 
acclimatization. The present study was undertaken with the objective of investigating the status of such parameters in embryo-cultured coconut plants. Based on such information, the levels of humidity, light and temperature during acclimatization could be altered to improve the growth and vigor of plants. This would ensure their survival once transferred to the field.

\section{MATERIALS AND METHODS}

\section{Plant material}

In-vitro grown coconut (Cocos nucifera L.) plants (improved variety CRIC 60) obtained from mature zygotic embryo culture were used for the study and nursery-raised coconut seedlings (five, nine and twelve-month-old) were used as the control.

\section{In-vitro culture conditions}

Mature embryos (11-12 months post anthesis) were surface sterilized for $5 \mathrm{~min}$ in $3 \%(\mathrm{w} / \mathrm{v})$ Calcium hypochlorite solution followed by thorough rinsing with sterile distilled water. The embryos were cultured in glass test tubes containing $10 \mathrm{ml}$ of the growth medium, modified Eeuwens $\mathrm{Y}_{3}$ liquid medium (Karunaratna et al., 1985), which was replenished each month. The $\mathrm{pH}$ of the medium was adjusted to 5.8 prior to the addition of activated charcoal, and the medium was autoclaved at $121^{\circ} \mathrm{C}$ and $1.05 \mathrm{~kg} \mathrm{~cm}^{-2}$ for 15 minutes. The cultures were incubated in the dark for two months. This was followed by incubation under $16 \mathrm{~h}$ photo periods for $4-5$ months. Towards the end of in vitro growth period, the plants were kept under $8.44 \mu \mathrm{mol} \mathrm{m}^{-2} \mathrm{~s}^{-1}$ light intensity. The incubation temperature was maintained at $29-30{ }^{\circ} \mathrm{C}$.

\section{Acclimatization of in vitro-grown plants}

Fifteen in vitro-grown plants were selected for acclimatization. The plants were removed from the test tubes, rinsed with water to wash out media off the roots and drenched in a fungicidal solution $(0.025 \%$ Benlate) before transferring to clear Polypropylene bags containing pre-sterilized potting medium (river sand, coir dust and cow dung, 2:1:1) moistened with a dilute fertilizer solution. To maintain high relative humidity, the bags were sealed at the top and kept under low light intensity (110-180 $\left.\mu \mathrm{mol} \mathrm{m}^{-2} \mathrm{~s}^{-1}\right)$. After three weeks, one end of the bag was cut to reduce the relative humidity. Subsequently at the end of fourth week, plants were fully exposed and kept under higher light intensity $\left(640-750 \mu \mathrm{mol} \mathrm{m} \mathrm{m}^{-2} \mathrm{~s}^{-1)}\right.$ for a period of three weeks. The plants were then repotted in larger polybags containing a potting mixture of top soil, dried cow dung and coir dust (2:2:1). Four months later, the plants were transferred to a plant house with higher light intensity $\left(1,000-1,200 \mu \mathrm{mol} \mathrm{m} \mathrm{m}^{-2} \mathrm{~s}^{-}\right.$ $\left.{ }^{1}\right)$ and were kept under this light intensity until field planting. The plants were watered 2-3 times a week and a liquid fertilizer was applied at two weekly intervals.

\section{Experimental procedure}

The anatomical, physiological and biochemical parameters of the acclimatizing plants were measured at four different stages (1-4, Fig.1) and compared with nursery-raised coconut seedlings of comparable growth. Stages 1 and 2 were compared with five-month old nursery-raised seedlings and stages 3 and 4 were compared with nine-month and eleven-month old seedlings, respectively. The stages are as follows.

\section{Stage 1} Stage 2

Just before transferring to ex-vitro conditions (light intensity $8.44 \mu \mathrm{mol} \mathrm{m}^{-2} \mathrm{~s}^{-1}$ )

\footnotetext{
Three weeks after transferring to ex-vitro conditions (light intensity $110-180 \mu \mathrm{mol} \mathrm{m}^{-2} \mathrm{~s}^{-1}$ ) Stage 3

Ten weeks after transferring to $e x$-vitro conditions (light intensity $640-750 \mu \mathrm{mol} \mathrm{m}^{-2} \mathrm{~s}^{-1}$ )
} 
Stage 4

Just before transferring to field (light intensity $1000-1200 \mu \mathrm{mol} \mathrm{m} \mathrm{m}^{-2} \mathrm{~s}^{-1}$ )

Determination of stomatal density and regulation of stomata

Epidermal impressions of the youngest fully open leaf were made, using the method similar to that described by Ranasinghe and Taylor (1996). A thin layer of transparent nail varnish was applied on the abaxial surface of the leaf and allowed to dry for 20-30 min. After drying, the nail varnish was gently peeled off with a blade, placed on a microscope slide and covered with a cover slip. The number of stomata per $\mathrm{mm}^{-2}$ (stomatal density) and number of open and close stomata were counted under x 400 magnification using a BH-2 Olympus light microscope (Olympus optical Co. Ltd., Tokyo, Japan) with eight replicas per plant.

\section{Determination of Epidermal cell parameters}

Using the above epidermal impressions, length and width of epidermal cells were measured using a calibrated eye piece graticule. A minimum of eight cells were measured from each plant.

\section{Determination of the thickness of leaf and epicuticular wax layer}

Samples were taken from central region of the youngest fully open leaf. For light microscopy, transverse sections of the leaf were stained in safranin and thickness of the leaf and epicuticular wax layer was measured using a calibrated eye piece graticule. For each plant, a minimum of eight sections were observed.

\section{Estimation of leaf chlorophyll content}

Youngest fully open leaf was sampled on ice, cut into small pieces and $0.03 \mathrm{~g}$ of fresh samples was homogenized in $5 \mathrm{ml}$ of $80 \%$ Acetone using an electric crusher (Ultra Turrax T-25, F G Bode and Co, GMBH, West Germany). During crushing, sample tubes were kept on ice to prevent temperature increase within the test tube and evaporation of Acetone. The crushed samples were centrifuged at $1500 \mathrm{rpm}$ for $5 \mathrm{~min}$ using a bench top centrifuge (Wifug Lab Centrifuge, 500-E, UK). The absorbance of the supernatant was measured at $645 \mathrm{~nm}$ and $663 \mathrm{~nm}$ using an UV-160A UV / VIS Recording Spectrophotometer (Shimadzu, Japan). Total chlorophyll content was calculated according to Arnon (1949).

\section{Determination of Rate of Transpiration and Photosynthesis}

Transpiration rate of the youngest fully open leaf was measured using the LI-1600 Steady Porometer (LI -COR Inc, Lincoln, USA) and Photosynthesis rate using the LI-6250 Portable Photosynthesis System ((LI -COR Inc, Lincoln, USA).

\section{Statistical Analysis of data}

Statistical analysis of the experimental data was made using the programme package SAS (Statistical Analysis System Institute, Carey, North Carolina, USA).

\section{RESULTS}

Stomatal characteristics of in vitro-raised coconut plants at four different stages of acclimatization and nursery-raised seedlings are summarized in Table 1. At the stage 1 of acclimatization, the percentage of open stomata was significantly higher in vitro-grown plants when compared to nursery-raised seedlings. However, at stages 2, 3 and 4 of acclimatization, there was no 
significant difference in \% open stomata between in vitro-grown and nursery-raised seedlings. A reduced level of $\%$ open stomata in vitro-grown plants was evident subsequent to the stage 1 of acclimatization process. The values at the three stages were in par with that of the nursery-raised seedlings. The stomatal density of in vitro-grown plants was found to be significantly lower than that of nursery-raised seedlings, except at the stage 4 of acclimatization. There was, however, an increase in stomatal density of in-vitro grown plants during the course of acclimatization (Fig. 2).

The epidermal cell length (Table 2) of in vitro-grown plants was significantly higher than that of nursery raised seedlings at the stage 1 of acclimatization whereas the cell width was significantly lower at the stages 1 and 2 of acclimatization. In the following stages of acclimatization, no significant difference was observed in epidermal cell length or width between in vitro-grown plants and nursery-grown seedlings. The epidermal cell length of in vitro-grown plants showed a decreasing trend during acclimatization whilst the cell width showed an increasing trend (Fig. 2).

The thickness of leaf and epicuticular wax layer was significantly lower in in vitro-grown plants when compared to nursery raised seedlings for the acclimatization stages 1, 2 and 3 (Table 3 ). However, the values were in par with that of nursery-raised seedlings at stage 4 of acclimatization. With the stages of acclimatization, the parameters also showed an increase in trend (Fig. 3).

Rate of transpiration, photosynthesis and total chlorophyll content of in vitro-grown plants at four different stages of acclimatization and nursery-raised seedlings are summarized in Table 4 . The rate of transpiration and photosynthesis at the stage 1 was not measured as the plants were within culture tubes. At the second and final stages of acclimatization, there were no significant differences in the rate of transpiration between in vitro-grown plants and the control. However, at the stage 3 of acclimatization, a five fold increase in the transpiration rate was observed in vitro-grown plants when compared to nursery-raised seedlings. As indicated in the table 4, the rate of photosynthesis in vitrogrown plants showed a significantly lower value than that of nursery-grown seedlings at the stage 2 of acclimatization. This position was, however, reversed at the stage 3 of acclimatization and was similar to that observed for rate of transpiration. At the stage 4 of acclimatization, the rate of transpiration and photosynthesis of in vitro-grown plants were similar to that of the control. Except at the stage 3 of acclimatization, the total chlorophyll content in the leaves of in vitro-grown plants was significantly higher when compared to nursery-raised seedlings (Table 4). The total chlorophyll content of in vitro-grown plants and nursery-raised seedlings varied between 1.41-2.03 and 0.97-1.63 mg g-1 fw, respectively during the period of acclimatization.

\section{DISCUSSION}

Plants which are raised in in vitro growth media in a water saturated atmosphere wilt rapidly on transfer to green house or field conditions. Therefore, in vitro-cultured plants require an acclimatization process in transition from culture to field conditions or green house. During the process of acclimatization, plants which are grown in an environment with low light intensity and high relative humidity are transferred to an environment with gradually increasing light intensity and decreasing relative humidity. It has been said that microclimate in culture vessel is one of the major factors affecting in vitro cultured explant physiology and morphology (Hughes, 1981). The main factors considered to be responsible for the specific effects are elevated relative humidity, gas composition inside the culture vessel, temperature and radiation parameters. Therefore in the present research, some of the anatomical, physiological and biochemical parameters of coconut plants during ex vitro growth were studied with the view of improving the current acclimatization protocol.

\section{Stomatal characteristics}

The present study indicated that the percentage of open stomata in leaves of in vitro-grown coconut plants, just before transferring to ex vitro conditions, was higher than that of nursery raised seedlings and this may be due to the unique culture vessel microclimate where high relative 
humidity, low light intensity and artificial gas atmosphere exists. Santamaria and Davies (1994) reported that unacclimatized leaves of in vitro-cultured delphinium plants had permanent stomatal opening or poor control of water loss. Stomata of in vitro-grown banana leaves were also found to be wide open (Ross-Karstens et al., 1998). These observations are comparable with the results obtained for in vitro-grown coconut plants. Towards the later stages of acclimatization, a decrease in the percentage of open stomata in vitro-grown coconut plants was observed and it was found to be in par with that of nursery-raised plants, thus indicating that the in vitro-grown coconut plants have adjusted to the external atmospheric conditions and attained a good control of stomatal regulation prior to being transferred to the field.

The stomatal density of in vitro-grown coconut plants was lower than that of nursery-raised seedlings at the initial stages and increased during the course of acclimatization. The improvement in light intensity may be one of the main contributory factors for the above result. Desjardins et al.(1998) also found an increase in the stomatal density in in vitro-grown strawberry leaves after raising the light intensity during propagation stage. Zacchini et al. (1997) showed that the highest stomatal density in leaves of Malus pumila and Prunus cersifera was induced by exposing them to continuous light while the lowest value was observed in the leaves grown under continuous dark.

\section{Leaf anatomy and morphology}

As a result of the low light intensity, the epidermal cells of in vitro-grown coconut plants were narrower and longer when compared to the control. With the exposure of plants to increased light intensity, the cells became wider and shorter as observed in the control. The characteristic response of 'sun' leaves to low light intensity is rapid leaf elongation (Sims and Pearcy, 1994). This is mainly attributed to the physiological mechanisms in response to the low radiation levels and such leaf elongation are commonly accompanied by increased epidermal cell elongation (Smith, 1982), as observed in the present study.

The development of epicuticular wax layer may help in the reduction of excess water loss and prevent plants from wilting once transferred to the field conditions. At the initial stages of acclimatization, the thickness of wax layer of in vitro-grown coconut plants was found to be lower than that of nursery-grown plants. However, the epicuticular wax thickness in vitro-grown plants was significantly increased towards the latter part of acclimatization. This indicates that the in vitrogrown coconut plants are capable of adjusting to the changes in external environment and can increase the secretion of wax layer with the increase in light intensity and decrease in relative humidity. Environmental factors such as light, humidity have been shown to affect wax production in leek plants (Post - Bettemiller, 1996). High relative humidity has been implicated in suppression of wax accumulation in in-vitro-grown cabbage and carnation leaves (Sutter and Langhans, 1979; Sutter, 1984). It has been shown that reduced humidity inside culture vessels increases the deposition of epicuticular wax layer on the leaves of Iris germanica (Maene and Debergh, 1986) and cauliflower (Short et al., 1987).

The leaf thickness was also found to be lower in in vitro-grown coconut plants than that of nursery raised coconut seedlings. Furthermore, it was observed that the leaf thickness of in vitrogrown plants steadily increased during acclimatization process and this may again probably in response to increased light intensity. Nii and Kurowia (1988) showed that sun-grown peach leaves were $29 \%$ thicker than the leaves grown in heavy shade because of greater thickness of both palisade and spongy parenchyma tissues and supporting the view, Sims and Pearcy (1994) have also revealed that the plants grown at higher light intensities are characterized by thicker leaves.

\section{Chlorophyll content}

Photosynthetic factors play an important role in plant acclimatization and survival. In the present investigation, higher chlorophyll contents were found in in vitro-cultured plants when 
compared to nursery raised seedlings. According to Triques et al. (1997), the chlorophyll content of coconut plants during in vitro growth was lower than that of an autotrophic palm. However, they did not find any significant difference in total chlorophyll content between in vitro-grown plants which are already acclimatized and autotrophic palm, as in the present investigation. In shaded leaves, increase in the chlorophyll content is an adoptive mechanism to increase photosynthetic rate. According to Nii and Kurowia (1988), chloroplasts of shaded leaves were larger and richer in thylakoids, whereas 'sun' leaves had poorly stacked grana. They also showed that starch accumulation in chloroplasts of sun leaves was markedly higher than that of shade leaves. Similarly, in the present study, starch accumulation in the leaves of nursery-raised coconut seedlings would have been higher under higher light intensity compared to in in vitro-grown plants. Therefore, a unit weight of leaf tissue sampled for chloroplast assay may have contained lesser number of chloroplasts in nursery raised seedlings when compared to in vitro-grown plants.

\section{Rates of photosynthesis and transpiration}

The results showed that the photosynthetic rate of in vitro-grown plants at the second stage of acclimatization was much lower than the rate observed at later stages as well as in nursery-grown plants. Carbon dioxide fixation of in vitro-grown plants at the second stage of acclimatization may be limited by low light intensity. At the third stage, the plants were exposed to optimum sunlight suitable for coconut, and as a result the photosynthetic rate was increased. This was probably a shortterm response to the increased light where rapid synthesis of carbohydrates must have taken place to compensate the lag period. The results also revealed that the photosynthesis rate of in vitro-grown plants at final stage of acclimatization was comparable to the control. The same trend was observed for the rate of transpiration.

In conclusion, in vitro-grown coconut plants exhibited a progress in improvement in stomatal regulation, photosynthetic capacity and related anatomical, physiological and biochemical characters comparable to that of nursery-raised seedlings indicating that they could adjust well to the changing environmental conditions during acclimatization and the plants can be considered fully acclimatized at the time of field planting.

\section{ACKNOWLEDGMENTS}

The authors gratefully thank Mrs. V R M Vidanaarachchi for supplying in vitro-raised plants for the study. Thanks are due to Ms. R Wimalasekara and Mrs. P S A De Saram of Plant physiology Division, Mrs. S Fernando, Mrs. C K Gamage and Mr. S Shantha of Tissue Culture Division and Mr. W E R Chandrasiri Fernando of Biometry Division for their skillful assistance. Thanks are extended to Dr. P S J W Serasinghe, Head, Department of Crop Science, Faculty of Agriculture, University of Ruhuna for his valuable comments. We also gratefully acknowledge the assistance of Mr. Pemsiri Silva and Mr. Ashoka Kumara the photographers. 
Table 1: Variation in stomatal characteristics of leaves of in vitro grown coconut plants $(\mathrm{E})$ at different stages of acclimatization and nursery raised seedlings $(\mathrm{N})$.

\begin{tabular}{|c|c|c|c|}
\hline Growth stage & $\begin{array}{c}\text { Growth } \\
\text { Condition }\end{array}$ & $\begin{array}{l}\text { \% Open } \\
\text { Stomata }\end{array}$ & $\begin{array}{c}\text { Stomatal } \\
\text { Density }\end{array}$ \\
\hline \multirow[t]{2}{*}{1} & $\begin{array}{l}\mathrm{E} \\
\mathrm{N}\end{array}$ & $\begin{array}{l}82.57 \\
60.53\end{array}$ & $\begin{array}{c}83.01 \\
132.84\end{array}$ \\
\hline & $\begin{array}{c}\text { Sig. } \\
\text { CV \% }\end{array}$ & $\begin{array}{c}* \\
23.62\end{array}$ & $\begin{array}{c}* * * \\
21.71\end{array}$ \\
\hline \multirow[t]{2}{*}{2} & $\begin{array}{l}\mathrm{E} \\
\mathrm{N}\end{array}$ & $\begin{array}{l}46.20 \\
60.53\end{array}$ & $\begin{array}{c}87.67 \\
137.84\end{array}$ \\
\hline & $\begin{array}{c}\text { Sig. } \\
\text { CV \% }\end{array}$ & $\begin{array}{c}* \\
41.99\end{array}$ & $\begin{array}{c}* * * \\
18.12\end{array}$ \\
\hline \multirow[t]{2}{*}{3} & $\begin{array}{l}\mathrm{E} \\
\mathrm{N} \\
\end{array}$ & $\begin{array}{l}58.92 \\
45.40 \\
\end{array}$ & $\begin{array}{l}107.93 \\
205.88 \\
\end{array}$ \\
\hline & $\begin{array}{c}\text { Sig. } \\
\text { CV \% }\end{array}$ & $\begin{array}{c}\text { Ns } \\
26.01\end{array}$ & $\begin{array}{c}* * * \\
12.37\end{array}$ \\
\hline \multirow[t]{2}{*}{4} & $\begin{array}{l}\mathrm{E} \\
\mathrm{N} \\
\end{array}$ & $\begin{array}{l}59.76 \\
62.55 \\
\end{array}$ & $\begin{array}{l}103.15 \\
118.74 \\
\end{array}$ \\
\hline & $\begin{array}{l}\text { Sig. } \\
\text { CV \% }\end{array}$ & $\begin{array}{c}\text { Ns } \\
9.66\end{array}$ & $\begin{array}{c}\text { Ns } \\
13.05\end{array}$ \\
\hline $\begin{array}{l}* \text {, significant at } \mathrm{p} \\
* * \text {, significant at } \mathrm{p} \\
\text { *** Significant at }\end{array}$ & $\begin{array}{l}\text { evel, } \\
\text { level, } \\
1 \text { level, ns, n }\end{array}$ & ant. & \\
\hline
\end{tabular}

Table 2: Variation in epidermal cell parameters of leaves of in vitro grown coconut plants $(\mathrm{E})$ at different stages of acclimatization and nursery raised seedlings $(\mathbf{N})$.

\begin{tabular}{|c|c|c|c|}
\hline Growth stage & $\begin{array}{c}\text { Growth } \\
\text { Condition }\end{array}$ & $\begin{array}{c}\text { Epidermal Cell } \\
\text { Length }(\mu \mathrm{m})\end{array}$ & $\begin{array}{l}\text { Epidermal Cell } \\
\text { Width }(\mu \mathrm{m})\end{array}$ \\
\hline \multirow[t]{2}{*}{1} & $\begin{array}{l}\mathrm{E} \\
\mathrm{N}\end{array}$ & $\begin{array}{l}72.25 \\
59.34\end{array}$ & $\begin{array}{l}10.42 \\
13.44\end{array}$ \\
\hline & $\begin{array}{l}\text { Sig. } \\
\text { CV \% }\end{array}$ & $\begin{array}{c}* * * \\
12.41\end{array}$ & $\begin{array}{l}* * * \\
9.27\end{array}$ \\
\hline \multirow[t]{2}{*}{2} & $\begin{array}{l}\mathrm{E} \\
\mathrm{N}\end{array}$ & $\begin{array}{l}67.10 \\
59.34\end{array}$ & $\begin{array}{l}12.13 \\
13.45\end{array}$ \\
\hline & $\begin{array}{l}\text { Sig. } \\
\text { CV \% }\end{array}$ & $\begin{array}{c}\mathrm{ns} \\
13.87\end{array}$ & $\begin{array}{c}* * \\
9.02\end{array}$ \\
\hline \multirow[t]{2}{*}{3} & $\begin{array}{l}\mathrm{E} \\
\mathrm{N}\end{array}$ & $\begin{array}{l}52.81 \\
49.26\end{array}$ & $\begin{array}{l}12.62 \\
13.51\end{array}$ \\
\hline & $\begin{array}{l}\text { Sig. } \\
\text { CV \% }\end{array}$ & $\begin{array}{c}\mathrm{ns} \\
10.46\end{array}$ & $\begin{array}{c}\mathrm{ns} \\
9.55\end{array}$ \\
\hline \multirow[t]{2}{*}{4} & $\begin{array}{l}\mathrm{E} \\
\mathrm{N}\end{array}$ & $\begin{array}{l}56.13 \\
56.20\end{array}$ & $\begin{array}{l}11.22 \\
11.37\end{array}$ \\
\hline & $\begin{array}{l}\text { Sig. } \\
\text { CV \% }\end{array}$ & $\begin{array}{c}\mathrm{ns} \\
7.24\end{array}$ & $\begin{array}{c}\mathrm{ns} \\
3.28\end{array}$ \\
\hline $\begin{array}{l}* \text {, significant at } \mathrm{p} \\
* * \text {, significant at } \mathrm{p} \\
* * * \text { significant at }\end{array}$ & $\begin{array}{l}\text { evel, } \\
\text { level, } \\
1 \text { level, ns }\end{array}$ & ficant. & \\
\hline
\end{tabular}


Table 3: Variation in the thickness of leaf and epicuticular wax layer of leaves of in vitro grown coconut plants $(E)$ at different stages of acclimatization and nursery raised seedlings $(N)$.

\begin{tabular}{|c|c|c|c|}
\hline Growth stage & $\begin{array}{l}\text { Growth } \\
\text { Condition }\end{array}$ & $\begin{array}{c}\text { Thickness of } \\
\text { wax layer }(\mu \mathrm{m})\end{array}$ & $\begin{array}{c}\text { Thickness of } \\
\text { leaf }(\mu \mathrm{m})\end{array}$ \\
\hline \multirow[t]{4}{*}{1} & $\mathrm{E}$ & 2.53 & 153.30 \\
\hline & $\mathrm{N}$ & 4.17 & 279.40 \\
\hline & Sig. & **** & $* * *$ \\
\hline & $\mathrm{CV} \%$ & 12.24 & 16.19 \\
\hline \multirow[t]{4}{*}{2} & $\mathrm{E}$ & 2.84 & 186.11 \\
\hline & $\mathrm{N}$ & 4.17 & 279.40 \\
\hline & Sig. & $* * *$ & $* * *$ \\
\hline & CV \% & 10.59 & 16.23 \\
\hline \multirow[t]{4}{*}{3} & $\mathrm{E}$ & 3.78 & 207.15 \\
\hline & $\mathrm{N}$ & 4.76 & 247.75 \\
\hline & Sig. & $* * *$ & $* *$ \\
\hline & $\mathrm{CV} \%$ & 87.43 & 11.07 \\
\hline \multirow[t]{3}{*}{4} & $\mathrm{E}$ & 4.30 & 298.07 \\
\hline & $\mathrm{N}$ & 3.65 & 282.98 \\
\hline & $\begin{array}{l}\text { Sig. } \\
\text { CV \% }\end{array}$ & $\begin{array}{c}\mathrm{ns} \\
19.34\end{array}$ & $\begin{array}{c}\mathrm{Ns} \\
16.09\end{array}$ \\
\hline \multicolumn{4}{|c|}{$\begin{array}{l}*, \text { significant at } \mathrm{p} \leq 0.05 \text { level, } \\
* *, \text { significant at } \mathrm{p} \leq 0.01 \text { level, } \\
* * * \text { significant at } \mathrm{p} \leq 0.001 \text { level, ns, not significant. }\end{array}$} \\
\hline
\end{tabular}

Table 4: Variation in rate of transpiration, rate of Photo and total chlorophyll content of leaves of in vitro grown coconut plants $(\mathrm{E})$ at different stages of acclimatization and nursery raised seedlings $(\mathbf{N})$.

\begin{tabular}{|c|c|c|c|c|}
\hline $\begin{array}{c}\text { Growth } \\
\text { stage }\end{array}$ & $\begin{array}{l}\text { Growth } \\
\text { Condition }\end{array}$ & $\begin{array}{c}\text { Rate of } \\
\text { Trans. }((\mu \mathrm{g} \\
\left.\mathrm{cm}^{-2} \mathbf{s}^{-1}\right)\end{array}$ & $\begin{array}{c}\text { Rate of } \\
\text { Photo. } \\
\left(\mu \mathrm{mol} \mathrm{m}^{-2} \mathrm{~s}^{-}\right. \\
\left.{ }^{-}\right)\end{array}$ & $\begin{array}{c}\text { Total } \\
\text { Chloro. } \\
\text { Content } \\
\left(\mathrm{mgg}^{-1} \mathbf{f w}\right)\end{array}$ \\
\hline 1 & $\begin{array}{l}E \\
N\end{array}$ & $\begin{array}{l}\text { Did not } \\
\text { measure }\end{array}$ & $\begin{array}{l}\text { Did not } \\
\text { measure }\end{array}$ & $\begin{array}{l}1.98^{\mathrm{a}} \\
1.25^{\mathrm{b}}\end{array}$ \\
\hline & $\begin{array}{c}\text { Sig. } \\
\text { CV \% }\end{array}$ & $\begin{array}{l}- \\
- \\
\end{array}$ & $\begin{array}{l}- \\
- \\
\end{array}$ & $\begin{array}{c}* * * * \\
20.64\end{array}$ \\
\hline 2 & $\begin{array}{l}\mathrm{E} \\
\mathrm{N}\end{array}$ & $\begin{array}{l}1.24 \\
1.97\end{array}$ & $\begin{array}{l}2.96 \\
6.57\end{array}$ & $\begin{array}{l}2.03 \\
1.25\end{array}$ \\
\hline & $\begin{array}{l}\text { Sig. } \\
\text { CV \% }\end{array}$ & $\begin{array}{c}\mathrm{ns} \\
52.45\end{array}$ & $\begin{array}{c}* * * \\
36.64 \\
\end{array}$ & $\begin{array}{c}* * * \\
17.36 \\
\end{array}$ \\
\hline 3 & $\begin{array}{l}\mathrm{E} \\
\mathrm{N}\end{array}$ & $\begin{array}{c}10.33 \\
1.97\end{array}$ & $\begin{array}{l}9.75 \\
6.57\end{array}$ & $\begin{array}{l}1.77 \\
1.63\end{array}$ \\
\hline & $\begin{array}{c}\text { Sig. } \\
\text { CV \% }\end{array}$ & $\begin{array}{c}* * * \\
52.45 \\
\end{array}$ & $\begin{array}{c}* * * \\
36.64 \\
\end{array}$ & $\begin{array}{c}\text { Ns } \\
18.68\end{array}$ \\
\hline 4 & $\begin{array}{l}\mathrm{E} \\
\mathrm{N}\end{array}$ & $\begin{array}{l}2.75 \\
3.99 \\
\end{array}$ & $\begin{array}{c}8.06 \\
10.32\end{array}$ & $\begin{array}{l}1.41 \\
0.97\end{array}$ \\
\hline & $\begin{array}{l}\text { Sig. } \\
\text { CV \% }\end{array}$ & $\begin{array}{c}\mathrm{ns} \\
33.35\end{array}$ & $\begin{array}{c}\mathrm{ns} \\
29.97\end{array}$ & $\begin{array}{c}* * * * \\
17.52\end{array}$ \\
\hline
\end{tabular}




\section{REFERENCES}

ARNON, D I 1949. Copper enzymes. Plant Physiol. 24:3-5.

DEBERGH, P C 1991. Acclimatization techniques of plants from in vitro Acta Hort 289:291-300.

DESJARDINS, Y, LAFORGE, F, LUSSIER, C AND GOSSELIN, A 1988. Effect of carbon dioxide enrichment and high photosynthetic photon flux on the development of autotropy and growth of tissues strawberry, raspberries and Asparagus plant. Acta. Hort. 230:45-53.

GUZMAN, E V DE and ROSARIO, D A 1964. The growth and development of Cocos nucifera L. "Makapuno" embryo. Philipp. Agr. 48:82-94.

HUGHES, K W 1981. In-vitro ecology: Exogeneous factors affecting growth and morphogenesis in culture systems. Environ. Exp. Bot. 21:281-288.

KARUNARATHNE, S, SANTHA, S and KOVOOR, A 1991. An in -vitro assay for drought-tolarent coconut germplasm. Euphytica 53:25-30.

KARUNARATHNA, S KURUKULAARACHCHI, C and GAMAGE C 1985. A report on the culture of embryos of dwarf coconut, Cocos nucifera L. var. nana, in vitro. Cocos 3: 1-8.

MAENE, L J and DEBERGH, P C 1986. Optimization of plant micro-propagation. Med Fac Landbouwet Rijsuni Gent 51: 1479-86.

MORINI, S, TRINCI, M and ZACCHINI, M 1991. Effect of different photoperiod on in-vitro growth of Mr.S.2/5 plum root stock. Plant cell Tiss. Org. Cult. 25:141-5.

NII, N and KUROWA, T 1988. Anatomical changes including chloroplast ultrastructure in peach leaves under different light condition. Jour. Hort. Sci. 63: 37-45.

POST-BEITTENMILLER, D 1996. Biochemistry and molecular biology of wax production in plants. Annu. Rev. Plant Physiol. Plant Mol. Biol. 47:405-30.

RANASINGHE, C S and TAYLOR, G 1996. Mechanism for increased leaf growth in elevated $\mathrm{CO}_{2}$. Journal of Expt. Bot. 47: 349-58.

ROSS-KARSTENS, G S, EBERT, G S and LUDDERS, P 1998. Influence of in vitro growth condition on stomatal density, index and aperture of grape, coffee and banana plantlets. Plant Tissue Culture and Biotech. 4:21-7.

RILLO, E P, PALOMA, MBF, RODRIGUEZ, B J and IGNACIO, M T R 1988. Screening of coconut populations for resistance to Cadang-cadang disease using in vitro cultured embryos. Philippine Coconut Authority, Albay Research Centre, Ann Report 1988: 39-40.

SHORT, K C, WARBURTON, J and ROBERTS, A V 1987. In vitro hardening of cultured cauliflower and chrysanthemum plantlets to humidity. Acta Hortic. 212:329-34.

SANTAMARIA, J M and DAVIES,W J 1994. Control of water loss by Delphininum plants cultured in vitro, In: PJ Lumsden, JR Nicolas, WJ Davies (eds), Physiology, growth and development of plants in culture, Kluwer, Dordrecht pp.155-164. 
SIMS, D A and PEARCY, R W 1994. Scaling sun and shade photosynthetic acclimation of Alocasia macrorriza to whole-plant performance-I. Carbon balance and allocation at different photo flux densities. Plant, Cell and Envir. 17:881-7.

SMITH, H 1982. Light quality, photoperception and plant strategy. Ann. Review of Plant Physiol. and Plant Mol. Biol. 33:481-518.

SUTTER, E and LANGHANS, R W 1979. Epicuticular wax formation on Carnation plantlets regenarated from shoot tip culture. J. Ame. Soc. Hortic. Sci.104:493-6.

SUTTER, E 1984. Chemical composition of epicuticular wax in cabbage plants grown in-vitro. J. Bot. 62:74-7.

TRIQUES, K, RIVAL, A, DEULE, T, PUARD, M, ROY, J, NATO, A, LAVERGNE, D. HAVAUX, M and HAMON, S 1997. Photosynthetic ability of in-vitro grown coconut plantlets derived from zygotic embryos. Plant science 127:39-51.

ZACCHINI, M, MORINI, S and VITGLIANO 1997. Effect of photoperiod on some stomatal characteristics of in vitro cultured fruit tree shoots. Plant cell Tiss. Org. Cult. 49:195-200 


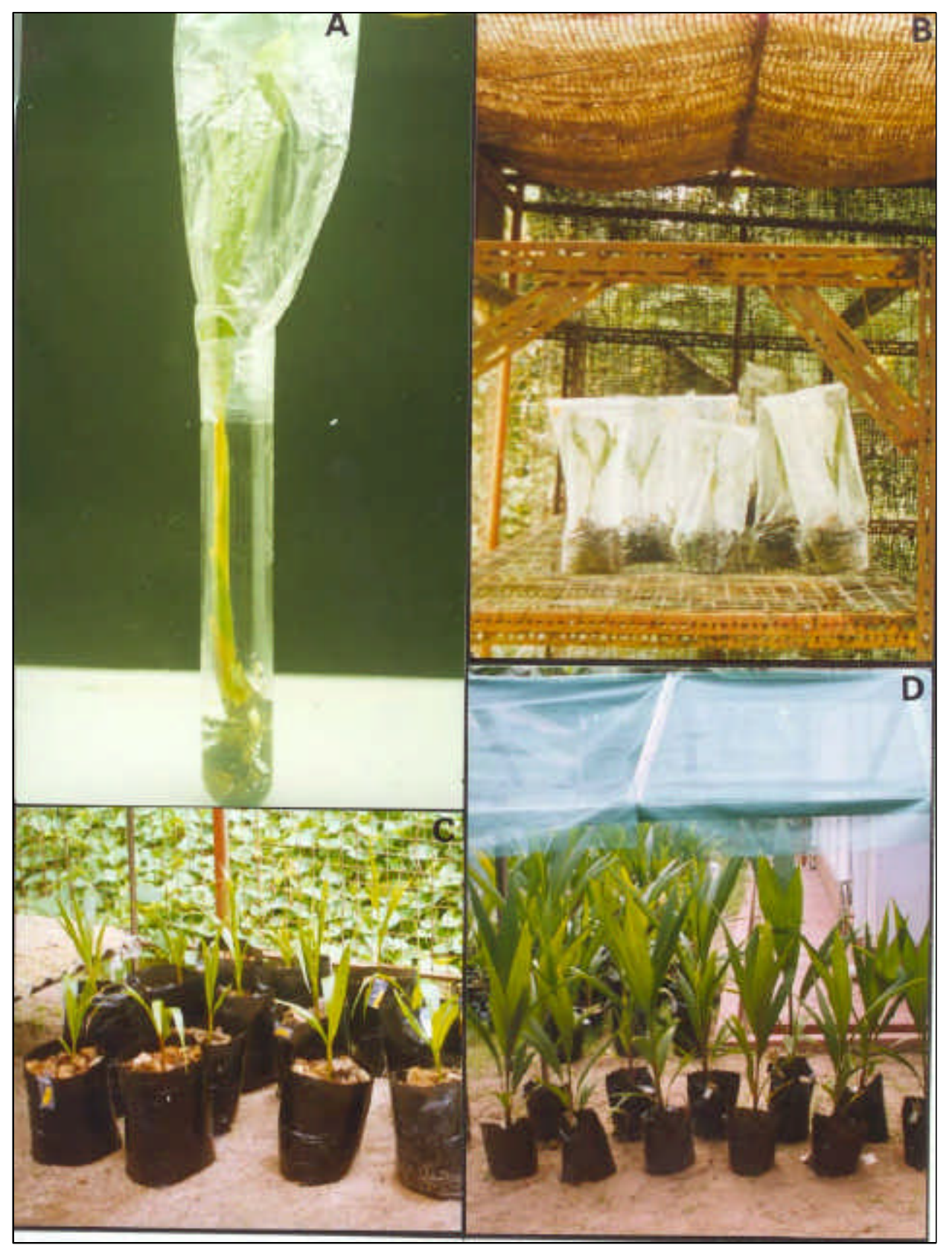

Figure 1: Different stages of acclimatization of in vitro-grown coconut palms, (A) stage 1 (B) stage 2 (C) stage 3 (D) stage 4 


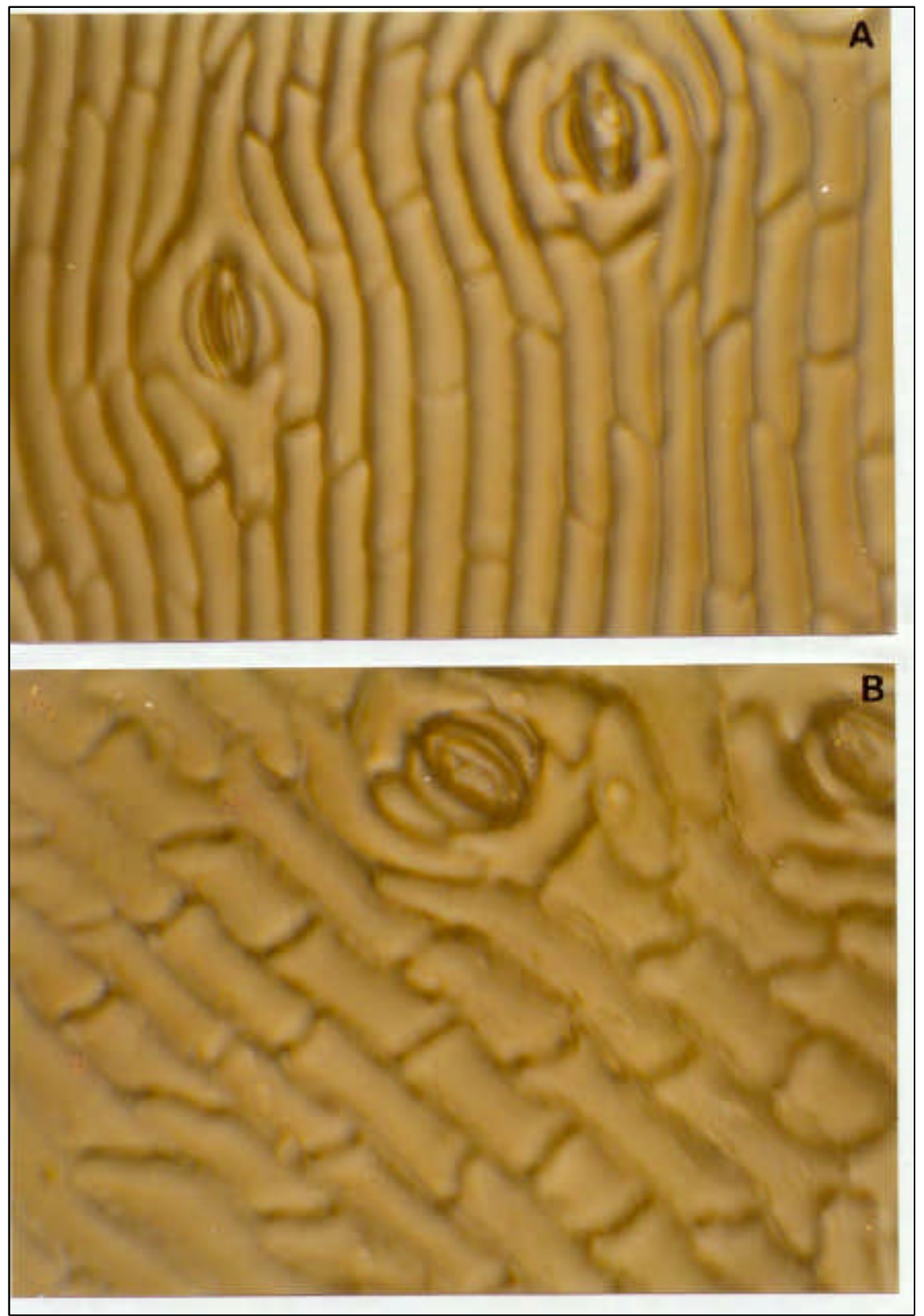

Figure 2: Epidermal impression of abaxial leaf surface of an in vitro-grown coconut plant at (A) stage 1 (B) stage 4 of acclimatization (X 400). 

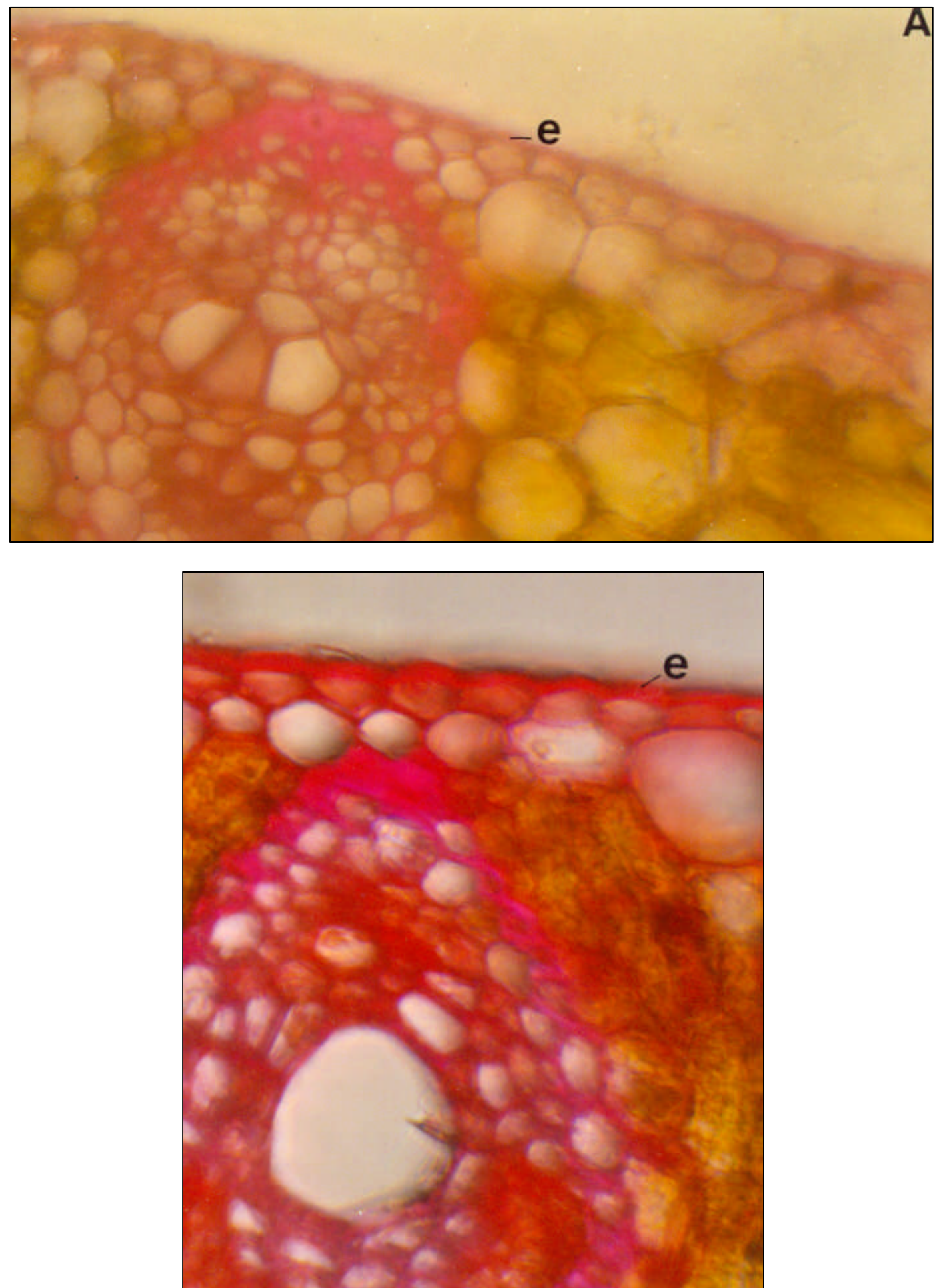

Figure 3: Cross section of a leaf of an vitro-grown coconut plant at (A) stage 1, (b) stage 4 of acclimatization. E, epicuticular wax layer. (X 400). 